\title{
ACCOUNT OF THE BUSINESS MEETING AT DUBROVNIK, 24/6/88
}

\section{WILLEM G MOOK}

1. Conventions: no changes were recommended regarding the conventional notations such as BP, cal BC/AD. Scales of calibration curves should be according to RADIOCARBON,v 28, no. 2B, (1986).

2. RADIOCARBON Journal: Austin Long has succeeded Minze Stuiver as the Editor; Renee Kra will continue as Managing Editor. Emphasis will be on articles, but publication of date lists and geophysical data remain possible.

3. Calibrations curves: the calibration group felt that the new overlap in dated periods (ca $900 \mathrm{yr}$ ) is not yet sufficient to present an extended recommended curve. Figure 1 presents the periods calibrated by various laboratories. Further progress will be possible at the next international conference. (A discrepancy between Belfast and Groningen for 3900$3000 \mathrm{cal} \mathrm{BC}$ has meanwhile been removed after the conference, see Mook $\&$ Becker, this issue).

4. Calibration procedure: the mathematical calibration technique of most laboratories is equal. The output differs: graphs and/or ranges. Several examples were presented during the conference showing that reporting medians (with or without standard deviations) is sometimes possible but, in general, not justified and, in most cases, in conflict with the true probability distribution. The conference felt that not one specific calibration program should (yet) be recommended.

5. Data Base (IRDB): in principle, an international ${ }^{14} \mathrm{C}$ data-base system has been agreed upon which is of a "catalogue type," containing sufficient information (ca 13 fields) to judge the suitability of the date. Full information is to be obtained from the local or regional data base. The International Radiocarbon Data Base (IRDB) will be directed by Renee $\mathrm{Kra}$, who will oversee the implementation of technical and practical details in Tucson, where the IRDB will be set up.

6 . Intercomparison: the results obtained by ca 40 laboratories on materials distributed by the Glasgow group (Marian Scott) received broad attention. The data show some interesting trends and features, although conclusions can only be general. Several laboratories feel that additional and different procedures are urgently required for establishing quality control. This matter will be discussed with the Isotope Hydrology Section of the International Atomic Energy Agency in Vienna (Dr. Gonfiantini), which efficiently runs the entire stable isotope intercomparison and standardization taken over from the US National Bureau of Standards. The ${ }^{14} \mathrm{C}$ laboratories were urged to cooperate in finishing the three-stage program of Glasgow. Marian Scott will seek support for an Intercomparison Workshop in Glasgow in September, 1989.

7. ${ }^{14} \mathrm{C}$ Conference 1991: Tucson was selected to organize the 14 th International Radiocarbon Conference. The month of May was selected. Austin Long will be the principal organizer. 
8. International Association of Radiocarbon Laboratories: a suggestion was discussed to unite radiocarbon laboratories into some kind of association. The majority of the participants did not feel the need for such an organization and showed restraints towards formal bodies. The meeting chairman concluded that the idea had not been sufficiently discussed informally during the conference.

9. Finally, the meeting chairman thanked Dr Dušan Srdoč and his coworkers for the organization of the conference and the hearty reception of the ${ }^{14} \mathrm{C}$ family members. Dubrovnik will be remembered as a fantastic place.

\section{Groningen, September 27, 1988}

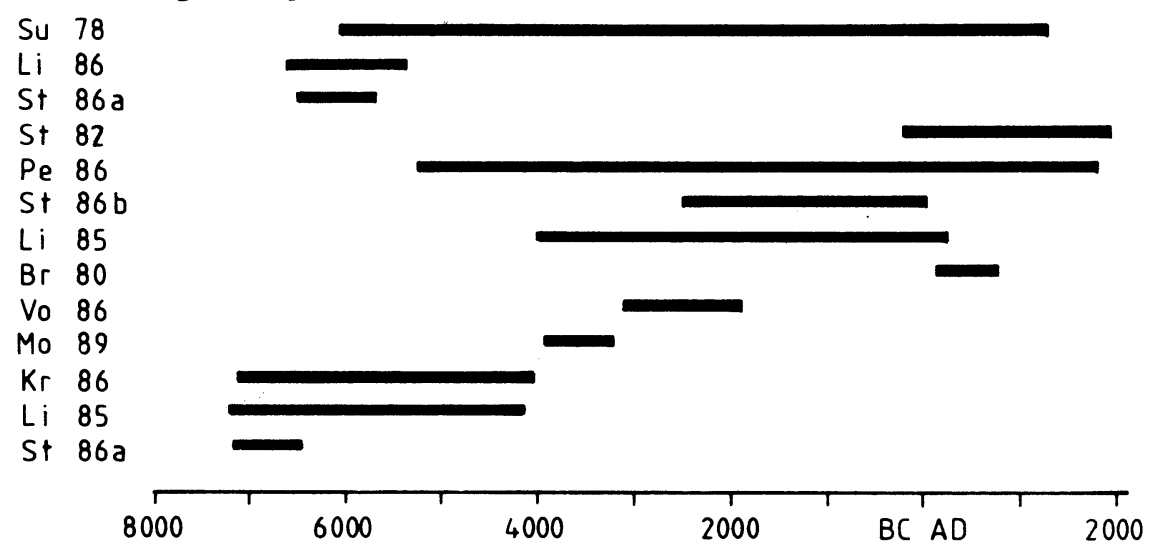

Fig 1. Periods calibrated by various laboratories and their references

Su 78 Suess, H E, 1978, La Jolla measurements of radiocarbon in tree-ring-dated wood: Radiocarbon, v 20 , no. $1, \mathrm{p} 1-18$

Li 86 Linick, T W, Long, A, Damon, P E and Ferguson, C W,1986, High-precision radiocarbon dating of bristlecone pine from 6554 to 5350 BC: Radiocarbon, v 28, no. $2 \mathrm{~B}, \mathrm{p}$ 943-953.

St 86a Stuiver, M, Kromer, B, Becker, B and Ferguson, C W, 1986, Radiocarbon age calibration back to 13,300 years $\mathrm{BP}$ and the ${ }^{14} \mathrm{C}$ age matching of the German oak and US bristlecone pine chronologies: Radiocarbon, v 28, no. 2B, p 969-979 (older part: German oak, younger part: bristlecone pine).

St 82 Stuiver, M, 1982, A high-precision calibration of the AD radiocarbon time scale: Radiocarbon, v 24 , no. 1 , p $1-26$.

Pe 86 Pearson, G W, Pilcher, J R, Baillie, M G L, Corbett, D M and Qua, F, 1986, High-precision ${ }^{14} \mathrm{C}$ measurement of Irish oak to show the natural ${ }^{14} \mathrm{C}$ variations from $\mathrm{AD} 1840-5210 \mathrm{BC}$ : Radiocarbon, v 28, no. 2B, p 911-934.

St 86b Stuiver, M and Becker, B, 1986, High-precision decadal calibration of the radiocarbon time scale, AD 1950-2500 BC: Radiocarbon, v 28, no. 2B, p 863-910.

Li 85 Linick, T W, Suess, H E and Becker, B, 1985, La Jolla measurements of radiocarbon in South German oak tree-ring chronologies: Radiocarbon, v 27, no. 1, p 20-32.

Br 80 Bruns, M, Münnich, K O and Becker, B, 1980, Natural radiocarbon variations from AD 200-800: Radiocarbon, v 22, no. 2, p 219-226 (German oak).

Vo 86 Vogel, JC, Fuls, A and Visser, E, 1986, Radiocarbon fluctuations during the third millennium BC: Radiocarbon, v 28, no. 2B, p 935-938 (German oak).

Mo 89 Mook, W G and Becker, B, 1989, Corrected calibration of the radiocarbon time scale: Radiocarbon, this issue, (German oak).

Kr 86 Kromer, B, Rhein, M, Bruns, M, Schoch-Fischer, H, Münnich, K O, Stuiver, M and Becker, B, 1986, Radiocarbon calibration data for the 6th to the 8th millennia BC: Radiocarbon, $v 28$, no. 2B, p 954-960. 